\title{
On the Feasibility of Iron or Chromium Substitution for Aluminium in the $\mathrm{Al}_{13}-\mathrm{Keggin}$ Ion
}

\author{
János B. Nagy,a Jean-Christophe Bertrand,a István Pálinkób and Imre Kiricsi*c \\ a Unité de Résonance Magnétique Nucléaire, Facultés Universitaires Notre-Dame de la Paix, 61 rue de Bruxelles, \\ Namur, B-5000 Belgium \\ ${ }^{b}$ Department of Organic Chemistry, József Attila University, Dóm tér 8, Szeged, H-6720 Hungary \\ c Applied Chemistry Department, József Attila University, Rerrich B. tér 1, Szeged, H-6720 Hungary
}

${ }^{27} \mathrm{AI}$ NMR measurements in the liquid and the solid state supplemented with chemical analysis of the mixed salts unambiguously reveal that neither tetrahedral nor octahedral aluminium can be substituted by either iron or chromium in $\mathrm{Al}_{13}$-Keggin ion salts prepared by conventional methods.

Modification of microporous materials often lead to substances with unusual physical and chemical properties. One such property, the ability to catalyse various transformations, can be drastically influenced by the isomorphous substitution of atoms in the framework or pillars of, for instance, zeolites and pillared layer materials, respectively. Isomorphous substitution changes catalytic properties in various ways, $e . g$. the size and acidity of the active sites may be altered or elements with redox properties can be incorporated.

For pillared layer clays (PILCs), it is hard to tell whether isomorphous substitution does indeed occur, or whether merely co-hydrolysis and then co-pillaring takes place resulting in the formation of mixed pillars. Although ions of virtually every element have been claimed to be introduced into the tetrahedral as well as octahedral positions of the $\mathrm{Al}_{13}-\mathrm{Keggin}$ ion $\left[\mathrm{AlO}_{4} \mathrm{Al}_{12}(\mathrm{OH})_{24}\left(\mathrm{H}_{2} \mathrm{O}\right)_{12}\right]^{7+}, 1$ the highly cited patent did not give any clear-cut evidence for this. Direct proofs for isomorphous substitution are accumulating slowly and only for ions of certain elements such as germanium ${ }^{2}$ and gallium. ${ }^{3}$ Papers have appeared in the literature reporting the success of substituting iron or chromium into the tetrahedral as well as the octahedral positions in the $\mathrm{Al}_{13}-\mathrm{Keggin}$ ion; ${ }^{4-9}$ proof, however, is vague, especially since the pillared materials were investigated instead of the salt containing the polyhydroxy cations used for pillaring. This is clearly inadequate because the pillaring agents for Fe-PILC or Cr-PILC are anything but ions of Keggin type. In two extreme cases reported by the same authors (one for iron ${ }^{8}$ and another for chromium ${ }^{9}$ ), the only proof presented was by citing ref. 1 .

Thinking over the problem, suspicion should arise at least for incorporating $\mathrm{Fe}^{3+}$ or $\mathrm{Cr}^{3+}$ to any of the positions, but especially the tetrahedral positions of the $\mathrm{Al}_{13}$-Keggin ion, since their large size $\left[\mathrm{Cr}^{3+}\right.$ octahedral $(0.76 \mathrm{~nm})$, ionic radius for tetrahedral coordination is not given; $\mathrm{Fe}^{3+}$ tetrahedral $(0.63 \mathrm{~nm}$, high-spin complex), octahedral $(0.69 \mathrm{~nm}$, low-spin complex, $0.79 \mathrm{~nm}$, high-spin complex) compared to $\mathrm{Al}^{3+}$, tetrahedral $(0.53 \mathrm{~nm})$, octahedral $\left.(0.68 \mathrm{~nm})^{10}\right]$ should introduce considerable strain to the polyhydroxy ion. While successful incorporation of $\mathrm{Fe}^{3+}$ into zeolitic frameworks (isomorphous substitution of iron for aluminium) is well proven, in this instance, the whole crystal can help release any strain. There is another problem with iron substitution. Each study reports the partial hydrolysis of $\mathrm{Fe}^{\mathrm{III}}$ in the presence of $\mathrm{AlII}$. It has been shown that in such a system the hydrolysis of the iron salt becomes extremely rapid, leading to various forms of iron hydrous oxides. ${ }^{11}$ Hydrolysis, however, can be slowed down when an iron(II) salt is applied, since FeILFe ${ }^{\mathrm{III}}$ oxidation must precede hydrolysis. Thus, only by use of an iron(II) salt can one have a chance to incorporate iron into the $\mathrm{Al}_{13}$-Keggin structure.

As far as $\mathrm{Cr}^{3+}$ is concerned, octahedral coordination is usually adopted. There are only very few examples of tetrahedrally coordinated $\mathrm{Cr}^{3+}$ and in such cases, the $\mathrm{Cr}^{3+}$ ion is at the centre of complex anion and the tetrahedron is highly distorted. ${ }^{12}$

In this contribution we show that, contrary to widespread belief, co-pillaring is a feasible way of modifying $\mathrm{Al}_{13}$-pillared layer clays when chromium or iron ions are the modifiers. Also in contrast to widespread practice we provide results obtained mostly on pillar precursors (ions in solution as well as in the crystalline state) instead of for pillared clays.

For the preparation of the $\mathrm{Al}_{13}$-Keggin ion partial hydrolysis of $\mathrm{AlCl}_{3}$ was applied, while for the synthesis of mixed or isomorphously substituted pillar ions the partial co-hydrolysis of $\mathrm{AlCl}_{3}$ and $\mathrm{CrCl}_{3}$, or $\mathrm{AlCl}_{3}$ and $\mathrm{FeCl}_{2}$, of varying composition were applied. The solution ${ }^{27} \mathrm{Al} \mathrm{NMR}$ measurements were applied (i) for checking the formation of the Keggin unit after the partial hydrolysis of $\mathrm{AlCl}_{3}$ and (ii) studying the composition of the filtrate after treating the solution containing the partially hydrolysed $\mathrm{AlCl}_{3}$ with $\mathrm{Na}_{2} \mathrm{SO}_{4}$ solution. This treatment led to the precipitation of a white crystalline material which was further studied by ${ }^{27} \mathrm{Al}$ MAS NMR spectroscopy. The sulfate salts of the co-hydrolysed $\mathrm{AlCl}_{3}+\mathrm{CrCl}_{3}$ or $\mathrm{AlCl}_{3}+\mathrm{FeCl}_{2}$ mixtures were also studied by ${ }^{27} \mathrm{Al}$ MAS NMR spectroscopy and the ratio of octahedral to tetrahedral aluminium was calculated from the integrated areas of the relevant resonances. Data are listed in Table 1.

Data in Table 1 clearly show that the Keggin unit was formed in solution (entry 1 ) and was precipitated by $\mathrm{Na}_{2} \mathrm{SO}_{4}$ (entries 2 and 3). Although the solid-state NMR spectra of the 'isomorphously substituted' Keggin-sulfate salts are complex, resonances belonging to aluminium sitting in octahedral or tetrahedral positions can be easily identified

Table 1 Data obtained by quantitative ${ }^{27} \mathrm{Al}$ NMR measurements

\begin{tabular}{|c|c|c|c|c|}
\hline Entry & Nominal composition & $\delta^{\circ}(\Delta H / \mathrm{Hz})$ & $\delta^{\mathrm{T}}(\Delta H / \mathrm{Hz})$ & $\mathrm{Al}_{\mathrm{O}} / \mathrm{Al}_{\mathrm{T}}$ \\
\hline & Samples in the solution phase & & & \\
\hline 1 & $\mathrm{Al}_{13}-\mathrm{Keggin}-\mathrm{Cl}(\mathrm{K} 1)$ & $-0.1(25)$ & $62.8(9)$ & 14.0 \\
\hline 2 & $\mathrm{~K} 1+\mathrm{Na}_{2} \mathrm{SO}_{4}$ filtrate ${ }^{a}$ & $0.0(25)$ & - & - \\
\hline & Samples in the solid state & & & \\
\hline 3 & $\mathrm{Al}_{13} \mathrm{SO}_{4}$ & 4.8 & 61.7 & 11.9 \\
\hline 4 & $\mathrm{Al}_{12} \mathrm{CrSO}_{4}^{b}$ & $-1.2,-10.1,-64.3,-107.4$ & 61.4 & 11.5 \\
\hline 5 & $\mathrm{Al}_{12} \mathrm{FeSO}_{4}{ }^{c}$ & $-10.0,-49,-107.2$ & 60.6 & 8.0 \\
\hline 6 & $\mathrm{Al}_{11} \mathrm{Fe}_{2} \mathrm{SO}_{4}^{d}$ & $-12.0,-64.9,-109.2$ & 61.4 & 6.5 \\
\hline
\end{tabular}

a After partial hydrolysis of the $\mathrm{AlCl}_{3}$ solution it was treated with $\mathrm{Na}_{2} \mathrm{SO}_{4}$ solution resulting in the precipitation of a solid material and the filtrate was subjected to $\mathrm{NMR}$ measurement. ${ }^{b}$ Initial $\mathrm{AlCl}_{3}: \mathrm{CrCl}_{3}$ ratio of $12: 1$. ${ }^{c}$ Initial $\mathrm{AlCl}_{3}: \mathrm{FeCl}_{2}$ ratio of $12: 1^{d}$ Initial $\mathrm{AlCl}_{3}: \mathrm{FeCl}_{2}$ ratio of $11: 2$. 
After integration the $\mathrm{Al}_{\mathrm{O}} / \mathrm{Al}_{\mathrm{T}}$ ratio decreases, instead of showing the tremendous increase that should occur if substitution in the tetrahedral position really takes place.

Incorporation of $\mathrm{Cr}$ (entry 4) seems to be negligible by comparison of the $\mathrm{Al}_{\mathrm{O}} / \mathrm{Al}_{\mathrm{T}}$ ratio with that for $\mathrm{Al}_{13}-\mathrm{SO}_{4}$ (entry 3 ) assuming that tetrahedral sites are not occupied by $\mathrm{Cr}$.

Similar $\mathrm{Al}_{\mathrm{O}} / \mathrm{Al}_{\mathrm{T}}$ ratios to those listed in Table 1 (entries 5 and 6) would be obtained for $\mathrm{Fe}, \mathrm{Al}$ salts if some degree of tetrahedral and significant octahedral substitution occurred. The ionic radius of octahedrally coordinated low-spin $\mathrm{Fe}^{3+}$ indicates that the octahedral positions may be accessible. However, chemical analysis of the $\mathrm{Fe}, \mathrm{Al}$ salts (dissolving the salt, titrating the iron and aluminium content) gave very low iron to aluminium ratios of $1: 80-100$ instead of $1: 12$ or $2: 11$ (entries 5 and 6). FT-IR ${ }^{13}$ on co-hydrolysed Keggin salts and ${ }^{57} \mathrm{Fe}$ Mössbauer measurements on $\mathrm{Fe}, \mathrm{Al}$ co-pillared montmorillonite ${ }^{14}$ also revealed that overwhelmingly co-precipitation occurred instead of tetrahedral or octahedral substitution and that a small amount of iron hydrous oxide covers the $\mathrm{Al}_{13^{-}}$ Keggin salt. This oxide, however, contains the iron in octahedral coordination.

This work was supported by the National Science Foundation of Hungary through grant T014275. The financial help is highly appreciated.

Received, 9th August 1995; Com. 5/05333A

\section{References}

1 D. F. W. Vaughan, US Pat., 1987, 4,666,877.

2 R. Bertram, S. Schönherr and H. Görz, Z. Chem., 1984, 24, 225; 1987, 27, 183.

3 S. M. Bradely and R. A. Kydd, J. Chem. Soc., Dalton Trans., 1993, 2407.

4 J. Barrault, C. Zivkov, F. Bergaya, L. Gatinau, N. Hassoun, H. van Damme and D. Mari, J. Chem. Soc., Chem. Commun., 1988, 1403.

5 Y.W. Lee and B. J. Tatarchuk, Hyperfine Interact., 1988, 41, 661; Y. W. Lee, R. H. Raythatha and B. J. Tatarchuk, J. Catal., 1989, 115, 159.

6 A. Kostapapas, S. L. Suib, R. W. Couglin and M. L. Occelli, Stud. Surf. Sci. Catal., 1989, 49, 399.

7 F. Bergaya, N. Hassoun, J. Barrault and L. Gaineau, Clay Miner., 1993, 28, 109.

8 D. Zhao, G. Wang, Y. Yang, X. Guo, Q. Wang and J. Ren, Clays, Clay Miner., 1993, 41, 317.

9 D. Zhao, Y. Yang and X. Guo, Zeolites, 1995, 15, 58.

10 F. A. Cotton and G. Wilkinson, Advanced Inorganic Chemistry, 5th edn., Wiley, New York, Chichester, Brisbane, Toronto, Singapore, 1988, pp. 1387-1388.

11 S. S. Singh and H. Kodama, Clays Clay Miner., 1994, 42, 606.

12 F. A. Cotton and G. Wilkinson, Advanced Inorganic Chemistry, 5th edn., Wiley, New York, Chichester, Brisbane, Toronto, Singapore, 1988, p. 680.

13 I. Kiricsi, A. Molnár, I. Pálinkó and K. Lázár, Stud. Surf. Sci. Catal., $1995,94,63$.

14 I. Pálinkó, K. Lázár, I. Hannus and I. Kiricsi, J. Phys. Chem. Solids, in the press. 